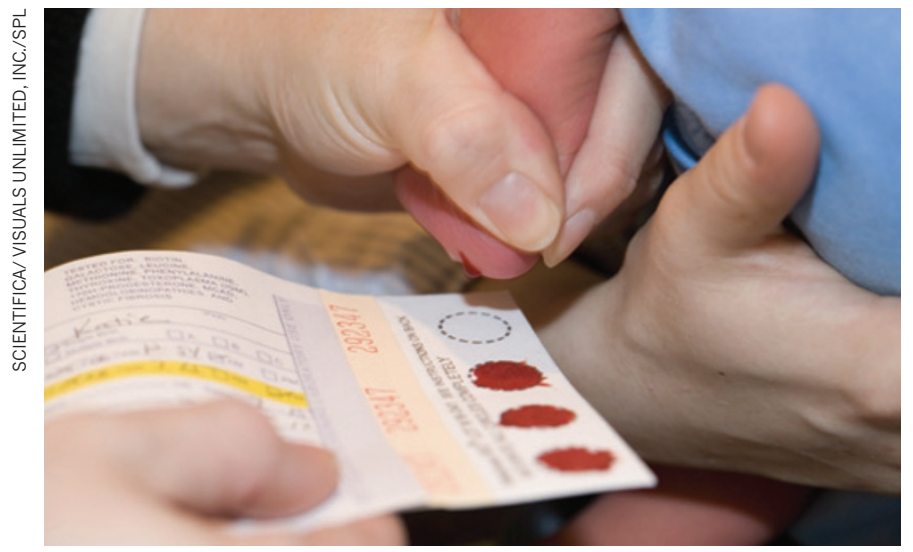

the Queen Mary University of London and their colleagues analysed DNA from the Guthrie cards of three healthy children born in 2000, looking for differences in patterns of DNA methylation, an epigenetic change that involves the addition of methyl groups to DNA. The researchers found about a dozen differences that were still present in samples taken three years later and did not seem to be linked to underlying genetic variation. This suggests that the changes might be the result of differences in conditions encountered in the womb.

Guthrie cards could help researchers to distinguish between epigenetic changes that are driving a disease and those that result from it. Genome Res. http://dx.doi.org/ 10.1101/gr.134304.111 (2012) For a longer story on this research, see http://go.nature.com/fgmz6w

\section{MEDICAL DEVICES}

\section{Smart way to seal cuts}

A 'smart' suture that doubles as a heater and a thermometer could promote wound healing.

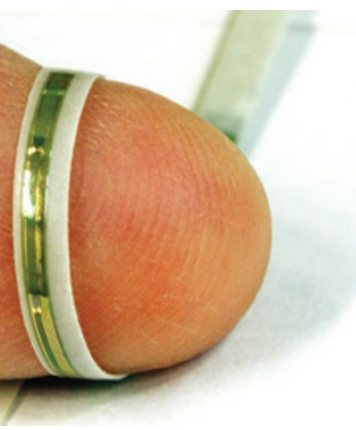

John Rogers of the University of Illinois at Urbana-Champaign and his colleagues have developed a prototype silicon-based suture (pictured) that is long, thin and flexible enough to be sewn into a wound. The suture contains circuit elements that can both heat tissue and sense its temperature. This enables the device to keep the wound at an ideal temperature for healing and to detect temperature increases associated with infection.

The researchers hope to develop sutures with other functions, such as programmable drug release. Small http://dx.doi.org/10.1002/ smll.201200933 (2012)

\section{PALAEONTOLOGY}

\section{Jagged jaws identify mollusc}

An analysis of the mouthparts of 505-million-year-old fossils suggests that the animals could be among the world's earliest molluscs.

Martin Smith of the

University of Toronto, Canada, analysed more than 300 fossils belonging to two early invertebrate groups, Odontogriphus and Wiwaxia, that have been variously classified as molluscs, annelids or a common ancestor. The fossils are from British Columbia's Burgess Shale, which provides a record of an explosion in new body forms that occurred around the Cambrian era (542 million to 488.3 million years ago).

The mouthparts of many of

COMMUNITY CHOICE

The most viewed papers in science

\title{
Equations in papers $=$ fewer citations
}

\section{HIGHLY READ \\ on www.pnas.org in July}

Biologists have a reputation for avoiding mathematics, and a study of citation rates shows that this is not misplaced.

Tim Fawcett and Andrew Higginson at the University of Bristol, UK, examined whether the inclusion of equations affected the citation rates of papers published in 1998 in three leading ecology and evolution journals. The authors found that papers received $28 \%$ fewer citations overall for each additional equation per page of the main text; for citations in experimental papers, this rose to $35 \%$.

The duo recommends that researchers use equations sparingly in their main article text to ensure that their ideas reach a wide audience.

Proc. Natl Acad. Sci. USA 109, 11735-11739 (2012)

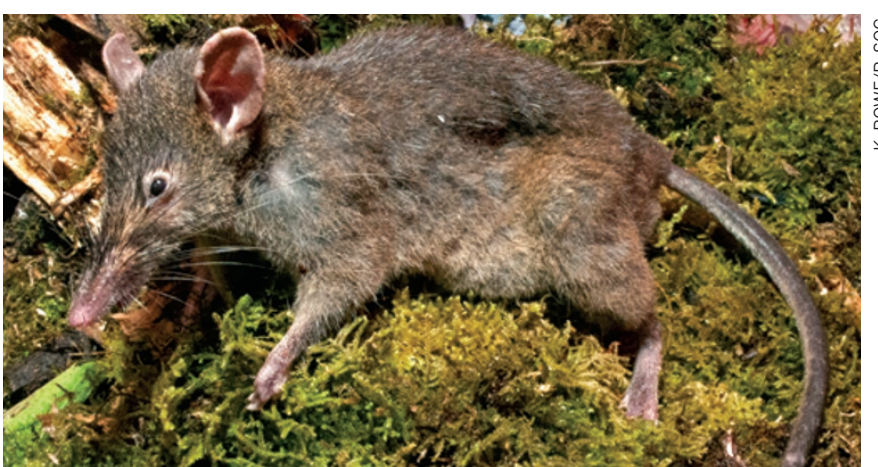

the fossils - rows of jagged teeth that rest on a grooved tongue - resemble those of modern-day molluscs. The teeth might have worked like a file, allowing the animals to grind soft tissues, the author suggests.

Proc. R. Soc. B http://dx.doi. org/10.1098/rspb.2012.1577 (2012)

\section{Rodent that cannot gnaw}

A shrew-rat that lacks molars and has oddly shaped incisors is an evolutionary anomaly among more than 2,200 known species of rodent.

Rats, mice and their kin owe their success in part to their ability to gnaw, which enables them to access foods that other mammals cannot.
Jacob Esselstyn of McMaster University in Hamilton, Ontario, and his colleagues report that the shrew-rat Paucidentomys vermidax (pictured) has a long, pointed face, incisors that differ in shape from those of other rodents, and no molars. These features could be adaptations that help the animal to find its favoured food - softbodied earthworms that do not need chewing. The loss of a previously successful evolutionary modification has allowed $P$. vermidax to take advantage of the available food in its forest home.

Biol. Lett. http://dx.doi. org/10.1098/rsbl.2012.0574 (2012)

\section{$\rightarrow$ NATURE.COM}

For the latest research published by Naturevisit:

www.nature.com/latestresearch 